Available online at: http://jurnal.stkippersada.ac.id/jurnal/index.php/PAUD

DUNIA ANAK: Jurnal Pendidikan Anak Usia Dini, 1 (2), November 2018

\title{
PERAN GURU DAN ORANGTUA MEMBANGUN NILAI MORAL DAN AGAMA SEBAGAI OPTIMALISASITUMBUH KEMBANG ANAK USIA DINI
}

\author{
Yohanes Berkhmas Mulyadi \\ STKIP Persada Khatulistiwa Sintang, Jln.Pertamina Sengkuang Km.4 \\ Email: yostellano@gmail.com
}

\begin{abstract}
Abstrak
Tujuan penelitian ini adalah untuk mengetahui peran guru dan orangtua membangun nilai moral dan agama sebagai optimalisasi tumbuhkembang anak usia dini. Penelitian ini bertolak dari sikap dan perilaku moral dan agama orang tua yang kurang optimal dalam kehidupan nyata. Jenis penelitian ini adalah deskriptif, dengan pendekatan kualitatif. Subjek penelitian ditentukan dengan teknik purposive sampling. Subjek Penelitian ini terdiri dari kepala sekolah, para guru dan orang tua anak TK Santa Maria Sintang. Pengumpulan data dalam penelitian ini dilakukan denganwawancara mendalam dan dokumentasi.Teknik analisis data dalam penelitian ini dengan melakukan reduksi data, kategorisasi, display/penyajian, dan pengambilan kesimpulan. Hasil penelitian menunjukkan bahwa guru dan orang tua sangat dibutuhkan perannya dalam menumbuhkan sikap dan perilaku moral dan agama seorang anak. Pembiasaan yang disertai dengan teladan dan diperkuat dengan penanaman nilai-nilai yang mendasari secara bertahap akan mengembangkan hubungan seorang anak dengan Tuhan Yang Maha Esa dan sesama. Manfaat penelitian adalah anak melakukan keutamaan dalam hidupnya khususnya keutamaan moral dan agama.
\end{abstract}

Kata kunci : Peran guru danorang tua, Nilai moral dan agama,Anak usia dini

\begin{abstract}
The purpose of this study was to determine the role of teachers and parents in building moral and religious values as an optimization of early childhood development. This study departs from the attitudes and moral behavior and religion of parents who are less than optimal in real life. This type of research is descriptive, with a qualitative approach. Research subjects were determined by purposive sampling technique. The research subject consisted of teachers and parents of TK St. Maria Sintang. Data collection in this study was conducted by indepth interviews and documentation. The data analysis technique in this study is by doing data reduction, categorization, display / presentation, and conclusion. The results showed that teachers and parents needed a role in fostering moral and religious attitudes and behaviors of a child. Habit that is accompanied by example and strengthened by planting underlying values will gradually develop a child's relationship with God Almighty and others. The benefit of research is that children carry out the virtues in their lives, especially moral and religious virtues.
\end{abstract}

Keywords : The role of parents, Moral and religious values, Early childhood 


\section{Dunia Anak: Jurnal Pendidikan Anak Usia Dini, 1 (2), November 2018 Yohanes Berkhmas Mulyadi}

\section{PENDAHULUAN}

Pertumbuhan merupakan bagian dari perkembangan, namun sebenarnya pertumbuhan danperkembangan adalah dua hal yang berbeda. Pertumbuhan adalah perubahan ukuran dan bentuk tubuh atau anggota tubuh, misalnya bertambah berat badan, bertambah tinggi badan, bertambah lingkaran kepala dan perubahan tubuh yang lainnya yang biasa disebut pertumbuhan fisik. Pertumbuhan dapat dengan mudah diamati melalui penimbangan berat badan atau pegukuran tinggi badan, Sunarto \& Hartono (2002).Adapun perkembangan adalah perubahan mental yang berlangsung secara bertahap dan dalam waktu tertentu, dari kemampuan yang sederhana menjadi kemampuan yang lebih sulit, misalnya kecerdasan, sikap, tingkah laku,bakat,minat. Proses perubahan mental ini terlebih dahulu melalui tahap pematangan. Bila saat kematangan belum tiba maka anak sebaiknya tidak dipaksa untuk meningkat ke tahap berikutnya misalnya kemampuan duduk atauberdiri,Hurlock (2011).

Saidah(2003) mengatakan bahwa pertumbuhan dan perkembangan masingmasing anak berbeda, ada yang cepat dan ada yang lambat, tergantung faktor bakat (genetik),lingkungan dan konvergensi (perpaduan genetika dan lingkungan).Moral berasal dari bahasa Latin "mores" yang berarti adat kebiasaan. Kholberg (2010) moral sering dsebut sebagai kata susila. Moral adalah sesuatu yang berhubungan dengan baik atau buruk, perilaku yang diterapkan oleh individu. Aspek moral tidak dibawa sejak lahir tetapi sesuatu yang berkembang karena dididik, diajari dan dipelajari, Menurut David Emile Durkheim (dalam Suseno, 2007)mengatakan agama adalah suatu sistem yang terpadu yang terdiri atas kepercayaan dan praktik yang berhubungan dengan hal yang suci. Dalam konteks ini, agama berhubungan dengan Tuhan.

Pertumbuhan dan perkembangan anak usia dini secara khusus dalam hal moral dan agama perlu direspon oleh guru dan orang tua karena nilai moral dan agama adalah basis spiritualitas anak. Seorang anak yang bertumbuh dan berkembang dalam kebaikan moral dan agama menjadi sumber keutamaan anak dalam melakukan kegiatan sehari-harinya, Hurlock (2011). Anak merupakan buah hati dan aset yang sangat bernilai dalam keluarga. Seorang anak dapat tumbuh dan berkembang dengan baik dan sehat menjadi orang dewasa yang sehat secara fisik, rohani, mental, sosial dan emosi, 


\section{Dunia Anak: Jurnal Pendidikan Anak Usia Dini, 1 (2), November 2018 Yohanes Berkhmas Mulyadi}

tergantung dari sekolah dan keluarga. Keluarga atau orang tua adalah panti utama dan pertama dalam proses pertumbuhan, perkembangan pendidikan anak,dan sekolah atau guru merupakan panti kedua pendidikan seorang anak, Gunarsa (2009).

Saidah (2003) pendidikan moral dan agama yang diberikan guru di sekolah dan orang tua di rumah berfungsi mengembangkan potensi dasar anak agar berhati baik, berpikiran baik, dan berperilaku baik. Potensi itu akanmenjadi sumber daya manusia yang berkualitas biladiterima seorang anak sejak kecil. Suyanto (2005) penelitian di bidang neurologi terbukti bahwa 50\% kapasitas kecerdasan anak terbentuk pada kurun waktu empat tahun pertama sejak kelahirannya.Pada saat anak mencapai usia delapan tahun maka perkembangan otak anak telah mencapai $80 \%$ hingga pada usia 18 tahun mencapai 100\%. Usia0-8 tahun merupakan masa emas perkembangan anak sebab $80 \%$ perkembangan otak berada pada rentang usiatersebut. Penelitian ini sudah diteliti oleh seorang neurolog Benyamin S. Bloom (Permono, 2013) mengatakan bahwa pertumbuhan sel jaringan otak pada anak usia 0-4 tahun mencapai 50\%, artinya bila pada usia tersebut otak anak mendapatkan rangsangan yang maksimal maka segala tumbuh kembang anak baik fisik maupun mental akan berkembang secara optimal dan pendidikan sejatinya harus dimulai usia tersebut. Dalam konteks ini, pendidikan yang dimulai usia taman kanak-kanak (TK) sebenarnya sudah terlambat,apalagi lebih terlambat kalau pendidikan baru bisa dimulai setelah usia sekolah dasar.

Suyadi (2010)peran yang sangat strategis dalam optimalisasi moral dan agama anak usia dini adalah guru dan orang tua. Kerjasama yang humanis antara guru dan orang tua adalah bagian yang intersant (penting) dalam membangun nilai moral dan agama. Orang tua adalah pendidik pertama dan utama bagi anakanak sejak lahir, usia dini sampai usia dewasa. Dalam proses pembentukan moral dan agama, watak, kepribadian, nilai-nilai budaya,keterampilan sederhana dibutuhkan peran ibu sebagai seorang pendidik pertama harus menjadi modeling bagi anak artinya orang tua pun seharusnya memiliki nilai moral dan nilai agama yang bisa ditunjukkan kepada anak.Peran guru dalam mengembangkan moral dan agama anak adalah lebih mengajak,memfasilitasi, membimbing dan mengajar anak usia dini supaya dapat mengerti tentang baik dan buruk secara moral dan mengetahui isi 


\section{Dunia Anak: Jurnal Pendidikan Anak Usia Dini, 1 (2), November 2018 Yohanes Berkhmas Mulyadi}

ajaran agama bagi pertumbuhan dan perkembangan iman anak.

Bentuk pendidikan moral dan agama di sekolah TK Santa Maria Sintang adalah melalui bermain peran, bernyanyi sambil bergerak, melatih cara membuka dan memakai kaus kaki, sepatu, membuang sampah di tempatnya, disiplin masuk sekolah, menghargai sesama, berbicara sopan, melaksanakan ibadah di gereja. Manfaat pendidikan moral dan agama disekolah TK Santa Maria Sintang adalah pertamaanak akan mendapat pengetahuan yang baik" (moral knowing), dan "merasakan dengan baik" (moral feeling), dan "perilaku yang baik" (moral action) serta melakukan ajaran agamanya (religi action). Habit atau kebiasaan yang terusmenerus dipraktekkan dan dilakukan anak usia dini akan menjadi karakter dalam dirinya (Mendiknas, 2011).

Permasalahan yang ditemukan dalam hal moral dan agama di sekolah TK Santa Maria Sintang adalah kurangnya pengetahuan anak akan moral dan agama, sarana dan prasarana yang mendukung pembelajaran masih kurang, tenaga pendidik yang kurang, tidak sopan dalam memakan jajan di depan guru karena kurangnya pengarahan dari orang tua ketika berada di rumah, berbicara kurang sopan Copyright $\odot$ 2018, DUNIA ANAK: Jurnal Pendidikan Anak Usia Dini, 1 (2), November 2018, e-ISSN 2621-4016 karena kurangnya pengajaran pendidikan agama di rumah, melempar mainan. Permasalahan ini perlu ditanggapi guru dan orang tua supaya anak mengerti dan menginternalisasi hal moral dan agama dalam kehidupan anak. Tujuan penelitian ini adalah untuk menjawab pertanyaan penelitian tentang (1) Seperti apa proses dalam membangun nilai moral dan agama yang dilakukan guru dan orang tua sebagai optimalisasi tumbuh kembang anak, (2) Faktor penghambat guru dan orang tua dalam membangun nilai moral dan agama sebagai optimalisasi tumbuh kembang anak, (3) Upaya yang dilakukan guru dan orang tua dalam membangun nilai moral dan agama sebagai optimalisasi tumbuh kembang anak.

\section{METODE}

Pendekatan dalam penelitian ini adalah kualitatif (qualitative approach), dengan jenispenelitian adalah deskriptif. Metode yang digunakan dalam penelitian adalah deskriptif analisis. Peneliti menggunakan pendekatan kualitatif karena hanya mendeskripsikan peran guru dan orangtua dalam membangun nilai moral dan agama sebagai optimalisasi tumbuh kembang anak usia dini.Tempat atau lokasi penelitian yaitu TK Santa Maria Sintang untuk mendapatkan data. Subyek dalam 


\section{Dunia Anak: Jurnal Pendidikan Anak Usia Dini, 1 (2), November 2018 Yohanes Berkhmas Mulyadi}

penelitian ini adalah segala sesuatu yang berkaitan dengan peran orang tua dalam membangun nilai moral dan agama yang dapat menunjang dalam memperoleh data. Subyek penelitian ditentukan dengan teknik purposive bersifat Snowball sampling artinya peneliti menentukan sendiri sampel yang diambil karena pertimbangan tertentu, (Sugiyono, 2012). Adapun yang menjadi subyek dalam penelitian ini adalah kepala sekolah TK St. Maria, para guru dan orang tua murid yang berjumlah sepuluhorang.

Tahapan pengumpulan data terdiri dari 3 tahap yaknitahap perencanaan, tahap pelaksanaan dan tahap analisis data. Tahap perencanaan dimulai dari mengurus perijinan dan administrasi terkait dengan rencana pelaksanaan penelitian. Pelaksanaan penelitian dimulai dengan menyusun instrument penelitian berupa panduan observasi, panduan wawancara, dan dokumentasi.Pada tahap pengumpulan data peneliti terjun ke TK Santa Maria untuk melakukan observasi, wawancara mendalam dan dokumentasi kepada responden terkait dengan peran guru dan orang tua dalam membangun nilai moral dan agama. Tahap selanjutnya yakni tahap analisis data, setelah selesai proses pengumpulan data diperolehsejumlah data kualitatif. Analisis dan pengolahan data berpedoman pada data yang terkumpul dari pertanyaan penelitian. Data kualitatif dari penelitian ini yaitu hasil pengamatan danwawancara. Data yang terkumpul dianalisis secaradeskriptif. Pada tahapanalisisdata, penelitian kualitatifbersifat induktif,bahwa semua kesimpulan dibentuk dari semua informan yang diperoleh dari lapangan. Teknik analisis data yang digunakan adalah teknik analisis data deskriptif kualitatif memanfaatkan persentase hanya merupakan langkah awal dari proses analisis data (Arikunto, 2009). Dalam proses selanjutnya analisisdata kualitatif terdiri dari empat alur kegiatan yang terjadi secara bersamaan, yaitu catatan lapangan, pengumpulan informasi, penyajian informasi, dan penarikan kesimpulan, Miles dan Huberman, dalam (Sugiyono, 2014). Analisis data dilakukan secara deskriptif (descriptive analysis). Hasil analisis data disajikan dalam bentuk laporan penelitian.

\section{HASIL DAN PEMBAHASAN}

Hasil

Hasil penelitian ini ditemukan berdasarkan wawancara guru dengan orang tua murid TK Santa Maria Sintang menunjukkan bahwa peran guru dan orang tua membangun nilai moral dan agama sebagai optimalisasi tumbuh kembang 
anak usia dini di TK Santa Maria Sintang adalah dalam bentuk bernyanyi, bermain peran, bercerita, berkaryawisata,outbound (kegiatan untuk bersatu dengan alam), pembiasaan, modeling (meniru), keteladanan dan bersyair, mengikuti ibadah. Anak dibiasakan berdoa di rumah, anak diajari untuk membedakan ini baik dan buruk, sopan dan tidak sopan,anak semangat dalam mengikuti pembelajaran di sekolah, meskipun masih ada anak yang tidak konsentrasi dalam pelajaran,anak tertib melaksanakan aturan sekolah. Nilai moral dan agama yang diterapkan di sekolah dan rumah adalah sopan santun, menghargai orang lain, menghormati orang tua dan sesama, mencintai diri dan lingkungan, membuang sampah pada tempatnya, berdoa sebelum dan sesudah pelajaran, mengikuti ibadah bersama di sekolah.Nilai agama adalah menyadari adanya Tuhan, melaksanakan ajaran Tuhan sesuai agama.Nilai moral agama sangat erat kaitannya dengan budi pekerti, sikap sopan santun, dan kemauan melaksanakan ajaran agama dalam kehidupan sehari-hari.

\section{Pembahasan}

Proses membangun nilai moral dan agama sebagai optimalisasi tumbuh kembang anak adalah melalui bermacam proses seperti proses bernyanyi dan bermain peran. Vivit Risnawati (2012)mengatakan dengan bermain peran anak akan mempunyai ksadaran merasakan jika ia menjadi seseorang yang dia perankan dalam kegiatan bermain peran. Proses diskusi dunia anak. Sapendi (2015) mengatakan metode diskusi dunia anak adalah untuk mendiskusikan tentang suatu peristiwa sederhana yang disertai dengan gambar atau memperhatikan sebuah tayangan dari $\mathrm{CD}$, kemudian setelah selesai siswa diajak berdiskusi tentang tayangan tersebut. Contenitas diskusi antara lain mengapa hal tersebut dilakukan, mengapa anak itu dikatakan baik, mengapa harus menyayangi orang lain.Proses bermain. Inawati Asti(2017)mengatakan nilai moral bermain adalah mau mengalah dalam permainan dan memotivasi untuk lebih semangat lagi dalam bermain.Proses bercerita, berkaryawisata,outbound (kegiatan untuk bersatu dengan alam).Secara psikologis anak TKmemiliki dorongan rasa ingin tahu, ingin mencoba segala sesuatu, dan ingin melakukan sesuatu yang belum pernah dialami atau dilakukannya maka melalui metode karyawsata, anak dapat mengembangkan aspek kognisi, afeksi dan psikomotoriknya sebab anak melihat langsung binatang, pekerjaan, kehidupan kota atau desa, 


\section{Dunia Anak: Jurnal Pendidikan Anak Usia Dini, 1 (2), November 2018 Yohanes Berkhmas Mulyadi}

pesisir, dan pegunungan ( Zainab, 2012). Proses outbond artinya suatu kegiatan yang memungkinkan anak untuk bersatu dengan alam, melalui kegiatan outbond siswa akan dengan leluasa menikmati segala bentuk tanaman, hewan, dan mahluk ciptaan Allah yang lain. Cara ini dilakukan agar terjadi sinkronisasi antara apa yang diajarkan di kelas dengan apa yang tampak di alam terbuka (Yunaida, dkk2018 ). Proses pembiasaan, modeling (meniru). Menurut Sujiono (2009) mengatakan meniru pada anak usia dini sangat kuat, tidak hanya meniru pada orang-orang disekitarnya tetapi juga pada tokoh-tokoh khayal yang sering ditampilkan ditelevisi, pada saat itu orang tua atau pengasuh harus menjadi tokoh panutan bagianak dalam berperilaku.Prosesbersyair dan keteladanan. Cahyatun Mchsunah, (2017) mengatakan keteladanan adalah guru moral ideal yang dapat menempatkan dirinya sebagai fasilitator, pemimpin, orangtua dan bahkan tempat menyandarkan kepercayaan, serta membantu orang lain dalam melakukan refleksi.

Faktor penghambat guru dan orang tua dalam membangun nilai moral dan agama sebagai optimalisasi tumbuh kembang anak, antara lain sikap anak yang kurang respon, orang tua yang tidak sinergis dengan harapan guru, temanteman sekolah, keterbatasan waktu di sekolah karena waktu belajar anak di TK hanya sekitar 120 menit, kesibukan orang tua, media masa, sikaporang tua, lingkungan. Gunarsa (2009)mengatakan keluarga adalah basis pembentukan fisik, psikologis dan sosial anak. Orang tua yang selalu sibuk dengan pekerjaan akan mengurangi keeratan psikologis anak dan orang tua. Kekurangaeratan ini mempengaruhi disposisi batin anak dalam menghayati nilai-nilai kehidupan yang diajarkan di sekolah seperti nilai moral dan agama.

Upaya yang dilakukan guru dan orang tua dalam membangun nilai moral dan agama sebagai optimalisasi tumbuh kembang anak, antara lain tingkatkan sarana prasarana, metode pembelajaran yang bervariasi, orang tua dukung pembelajaran di sekolah,guru lebih profesional, kepala sekolah terlibat langsung dalam program pembelajaran di sekolah sehingga menjadi penyemangat bagi para pendidik dan lingkungan yang kondusif, semangat peserta didik dalam mengikuti kegiatan belajar, pembiasaan melakukan hal positif seperti membuang sampah pada tempatnya, sikap mendengarkan yang baik, bernyanyi 


\section{Dunia Anak: Jurnal Pendidikan Anak Usia Dini, 1 (2), November 2018 Yohanes Berkhmas Mulyadi}

bersama, peduli bagi teman yang sakit, guru mewajibkan anak-anak TK Santa Maria untuk mengikuti ibadah yang dilakukan di sekolah.

\section{KESIMPULAN}

Setiap anak adalah pewaris keluarga dan bangsa yang perlu mendapat pendidikan yang baik sehingga potensipotensi dirinya dapat berkembang secaraoptimal. Anak yang terampil, mandiri dan berkualitas dari segi moral dan agama dilalui sebuah proses belajar. Guru dan orang tua berperan dan bertanggungjawab dalam memberikan berbagai macam stimulasi dan bimbingan yang tepat sehingga akan tercipta pewaris yang berakhlak dan bertingkah laku yang sesuai dengan norma kehidupan. Proses pembangunan nilai-nilai moral dan agama anak TK Santa Maria Sintangdilakukan dengan macam cara antara lain bernyanyi, bermain, berkaryawisata, outbond, bermain peran, bercerita, bersyair dan keteladanan serta berdoa bersama atau beribadah. Saran peneliti bagi penelitiselanjutnya yaitu kiranya lebih intens mengkaji nilai moral dan agama anak usia dinisupaya mendapat inovasi baru dalam pembelajaran dan harapannya anak anak dapat menjadi manusia yang bermoral dan berakhlak mulia.

\section{DAFTAR PUSTAKA}

Arikunto, S. (2009). Prosedur Penelitian SuatuPendekatan Praktik. Jakarta: Rineka Cipta

Asti Inawati. ( 2017). Strategis Pengembangan Moral dan Nilai Agama untuk Anak Usia Dini, Jurnal Pendidikan Anak, Vol.3. No. 1

Gunarsa. (2009). Asas-Asas Psikologi Keluarga Idaman. Jakarta : BPK Gunung Mulia

Hurlock. (2011). Psikologi Perkembangan. Jakarta : Erlangga

Kohlberg. L. \& Richard H Hersh. (2010).

"Moral Development : a Review of the theory", Theory into Practice. Vol. 16, No. 2

Machsunah, Yayuk Chayatun. (2017). Penanaman Pendidikan Karakter Melalui Keteladanan Pendidik (Studi Kasus di LBB Taman Pintar: Sahabat Sekolah Anak Lamongan). Journal STKIP PGRI Lamongan, Vol.1 No.2

Mendiknas. (2011). Pedoman PelaksanaPendidikan Karakter.Jakarta : Puskurbuk.

Permono, H. (2013). Peran Orang tua dalam Optimalisasi Tumbuh Kembang Anak untuk MembangunKarakter Anak Usia Dini. Prosiding Seminar Nasional Parenting. Hal. 34-47. Jakarta : Univ.Persada Indonesia

Risnawati, Vivit. (2012). Optimalisasi 
Pendidikan Karakter Anak Usia Dini Melalui SentraMain PeranTaman Kanak-Kanak Padang. Jurnal Pesona Paud, Vol.1.No. 2

Saidah, E.S (2003). Pentingnya Stimulasi Mental Dini Padu. Jurnal Ilmiah PAUD. Vol.2 No.51

Sapendi. (2015). Internalisasi Nilai-Nilai Moral Agama Pada Anak Usia Dini. At-Turats, Vol. 9.No.2

Sugiyono, (2012). Metode Penelitian Pendidikan, Pendekatan Kuantitatif, Kualitatif \& $R \& D$. Bandung: PT. Alfabeta. ...(2014).MetodePenelitian Pendidikan,PendekatanKuantitatif, Kualitatif \& $R \& D$.Bandung: PT.Alfabeta.

Sujiono, Y.N. (2009). Konsep Dasar Pendidikan Anak Usia Dini. Jakarta : PT. Indeks.

Sunarto, H. \& Hartono, A. (2002).
Perkembangan Peserta

Didik.Jakarta : Rineka Cipta

Suseno. (2010). Etika Dasar, MasalahMasalah Pokok Filsafat

Moral.Yogyakarta : Kanisisus

Suyadi. (2010) . Psikologi Belajar Anak Usia Dini. Yogyakarta : PT. Pustaka Aadani

Suyanto,S. (2005). Konsep Dasar Pendidikan Usia Dini. Jakarta. Diknas Dirjen Dikti

Yunaida, dkk (2018). Outbound Berbasis

Karakter Sebagai Media Pembelajaran Anak Usia Dini. Comm-Edu (Community Education Journal), Vo. 1 No.1

Zainab. (2012). Peningkatan Perkembangan Moral Anak Melalui Metode Cerita BergambarTK Lembah Sari Agam. Jurnal Pesona Paud, Vol 1. No.3 